\title{
THE METHOD OF PROCESSING TECHNOGENIC TAILINGS OF CHROMIUM
}

\section{S. Dyussenova1\#, B. Kenzhaliyev¹, R. Abdulvaliyev¹, S. Gladyshev¹}

\author{
1Satbayev University, Institute of Metallurgy and Ore Beneficiation JSC, \\ Almaty, Kazakhstan
}

(Received: October 1, 2019; Accepted: January 22, 2020)

\begin{abstract}
Taking into account the existing demand for chromium concentrates, the extraction of chromium from technogenic formations of sludge storages of the tailings of chromium ore beneficiation is an important practical task. The comprehensive utilization of beneficiation sludge will increase the profitability of production and solve the environmental problems of the region.

The importance of solving the problem of involving in processing tailings is connected not only with the environment but also with the need to increase the production of chromium. Modern gravity enrichment technologies make it possible to efficiently produce chromium concentrates from large and medium fractions of chromite-containing ores, while finely divided sludge is practically not extracted due to the difficulty of separating complex minerals into concentrates and waste rock. This paper presents the results of studies on the gravity processing of tailings.

The technology includes the enrichment of the fine fraction $-0.2+0 \mathrm{~mm}$ of tailings of the dressing plant of chromite-containing ores by gravity methods using a KNELSON centrifugal separator. In technology, the efficiency of the operation of gravity enrichment is provided by the preliminary activation of the fine fraction in a solution of sodium bicarbonate $\left(\mathrm{NaHCO}_{3}\right)$.

With gravitational enrichment, the total chromite concentrate was obtained containing $51.3 \% \mathrm{Cr}_{2} \mathrm{O}_{3}$. The output of concentrate was $41.7 \%$. The extraction of $\mathrm{Cr}_{2} \mathrm{O}_{3}$ in the concentrate was $68.1 \%$.
\end{abstract}

Key words: Chromite-containing ore; Gravity concentration; Tailings; Concentrate.

\section{Introduction}

The world practice is characterized by an increased interest in researching the processing of poor chrome ores, an increase in the recoverability of useful components from tailings and dumps, as well as the integrated use of ores [1 - 2].

In recent years, China has taken a leading position in the production of ferrochrome, and the new technology for producing ferrochrome in DC electric arc furnaces is widely used (DC-furnace). Unlike the classical AC-furnace technology, this technology successfully uses thin chromite concentrates that do not require preliminary agglomeration [3]. Major producers of chromite raw materials are also increasing the production of fine chromium concentrates. In particular, such concentrates in some mines in South Africa are obtained from the waste originating from the extraction of platinoids of the UG-2 formation. In Turkey, one of the leaders in chromite production, the ore reserves amount to 26.6 million tons, with an average content of $20 \%$ $\mathrm{Cr}_{2} \mathrm{O}_{3}$ and another 400 million tons of the poorer chromium ores are seen as a resource potential for use in the near future [4]. Currently, the Oregon Mineral Sands project is being implemented in the United States, the goal of which is the industrial development of the beach sands of the Pacific coast. The main useful component is chrome spinel, although its content in the sands does not exceed $10 \%$. The total amount of reserves and resources in the fields of the project is 11.23 million tons, with an average content of $8.1 \%$ chromite (less than $5 \% \mathrm{Cr}_{2} \mathrm{O}_{3}$ ).

Based on the above, deposits with even a very low $\mathrm{Cr}_{2} \mathrm{O}_{3}$ content are in demand.

In the present work, the issue of developing an effective technology for the integrated processing of chrome ore tailings from the Don Mining and Processing Plant (DGOK, Republic of Kazakhstan) with the production of finely dispersed chromite concentrate and the associated extraction of other useful components

\#Corresponding author: dusenova_s@mail.ru

doi: 10.5937/JMMA2001015D 
that increase the profitability of production was studied.

Taking into account the existing demand for chromium concentrates, the additional extraction of chromium from technogenic formations of sludge storages of the tailings of chromium ore beneficiation is an important practical task. The comprehensive utilization of the enriched sludge will increase the profitability of production and solve the environmental problems of the region.

The importance of solving the problem of involving in processing tailings is connected not only with the environment but also with the need to increase the production of chromium. Modern gravity separation technology can effectively get chrome concentrates large and medium fractions of chromium ores, and fine sludge is hardly extract because of the difficulty of separating complex minerals concentrates and waste rock [5]

\section{Materials and methods}

Chemical analysis was performed on an Optima 2000 DV inductively coupled plasma optical emission spectrometer (United States, PerkinEImer). X-ray phase analysis of the samples was carried out using a D8 Advance instrument (Bruker AXS $\mathrm{GmbH}$ ), a-Cu, voltage on the x-ray tube 40/40. The processing of the obtained diffractogram data and calculation of interplanar distances were carried out using the EVA software. The decoding of the samples and phase search was performed using the Search/match program using the ASTM Card Database.

Table 1 and 2 show the chemical and phase composition of the original sample.

Table 1 Chemical analysis of tailings

\begin{tabular}{|c|c|c|c|}
\hline Element & Content, $\%$ & Element & Content, \% \\
\hline $\mathrm{Cr}_{2} \mathrm{O}_{3}$ & 25.47 & $\mathrm{Cu}$ & 0.008 \\
\hline $\mathrm{Fe}_{2} \mathrm{O}_{3}$ & 9.1 & $\mathrm{~Pb}$ & 0.05 \\
\hline $\mathrm{SiO}_{2}$ & 21.53 & $\mathrm{As}$ & 0.025 \\
\hline $\mathrm{Al}_{2} \mathrm{O}_{3}$ & 1.51 & $\mathrm{Sb}$ & 0.23 \\
\hline $\mathrm{H}_{2} \mathrm{O}$ & 7.8 & $\mathrm{~K}$ & 0.05 \\
\hline $\mathrm{CaO}$ & 0.75 & $\mathrm{Na}$ & 0.05 \\
\hline $\mathrm{MgO}$ & 29.4 & $\mathrm{P}$ & 0.008 \\
\hline $\mathrm{MnO}_{2}$ & 0.053 & $\mathrm{C}$ & $<0.2$ \\
\hline $\mathrm{S}$ & 0.1 & $\mathrm{Ag}, \mathrm{g} / \mathrm{t}$ & $<2.0$ \\
\hline $\mathrm{Zn}$ & 0.1 & $\mathrm{Au}, \mathrm{g} / \mathrm{t}$ & $<0.05$ \\
\hline $\mathrm{Co}$ & 0.02 & $\mathrm{Ni}$ & 0.28 \\
\hline
\end{tabular}

Table 2 X-ray phase analysis of tailings

\begin{tabular}{|c|c|c|}
\hline Phase name & Formula & $\begin{array}{c}\text { The content } \\
\text { of the } \\
\text { phase, } \%\end{array}$ \\
\hline Antigorite & $\mathrm{Mg}_{3} \mathrm{Si}_{2} \mathrm{O}_{5}(\mathrm{OH})_{4}$ & 41.8 \\
\hline Clinochrysotile & $\mathrm{Mg}_{3} \mathrm{Si}_{2} \mathrm{O}_{5}(\mathrm{OH})_{4}$ & 5.1 \\
\hline Lizardite-1T & $\left(\mathrm{Mg}, \mathrm{Al}_{3}\left(\mathrm{Si}_{,}, \mathrm{Fe}_{2} \mathrm{O}_{5}\right)(\mathrm{OH})_{4}\right.$ & 12.5 \\
\hline $\begin{array}{c}\text { Aluminum } \\
\text { Ferrous } \\
\text { Magnesite }\end{array}$ & $\mathrm{MgAl}_{6} \mathrm{Fe}_{1.4} \mathrm{O}_{4}$ & 8.7 \\
\hline Chromite & $\left(\mathrm{Fe}_{0.52} \mathrm{Mg}_{0.48}\right) \mathrm{Cr}_{0.72}\left(\mathrm{Al}_{0.28}\right) \mathrm{O}_{4}$ & 15.3 \\
\hline Clinohlore & $\mathrm{Mg}_{6} \mathrm{Si}_{4} \mathrm{O}_{10}\left(\mathrm{OH}_{8}\right.$ & 5.6 \\
\hline $\begin{array}{c}\text { Aluminum } \\
\text { Magnesium } \\
\text { Silicate }\end{array}$ & $\mathrm{Ca}_{23.20} \mathrm{Mg}_{22.4}\left(\mathrm{Al}_{92} \mathrm{Si}_{100} \mathrm{O}_{384}\right)$ & 11.0 \\
\hline
\end{tabular}

\section{Results and discussion}

In order to improve the performance of the gravitational enrichment of chromite-containing sludge, a method was developed for preliminary chemical activation in the solution of sodium bicarbonate. Processing the initial ore with a solution of sodium bicarbonate leads to a change in the mineral structure of the chromite-containing ore.

Chemical activations of chromite-containing sludge were treated with a solution containing $120 \mathrm{~g} / \mathrm{dm}^{3}$ $\mathrm{NaHCO}_{3}$ at temperatures of $100-240{ }^{\circ} \mathrm{C}$, duration 90 minutes, ratio $L: S=10.0$, and adding a gas containing $12-14 \% \mathrm{CO}_{2}$ to the pulp at a gas ratio $\mathrm{V}: \mathrm{V}$ pulps equal to $1 \div 3: 1$ per minute $[6,7]$.

The required content of $120 \mathrm{~g} / \mathrm{dm}^{3}$ of sodium bicarbonate in the solution was selected, taking into account its solubility limit. The required temperature of $100-240{ }^{\circ} \mathrm{C}$ for the processing the feedstock with a solution of sodium bicarbonate was determined experimentally and involved the use of an autoclave. At temperatures below $100{ }^{\circ} \mathrm{C}$, the occurrence rate of the processes of changes in the mineral structure is low. An increase in the processing temperature above $240{ }^{\circ} \mathrm{C}$ is not justified, since this does not lead to additional changes in the mineral structure of the raw material.

It is known that at temperatures of $60-200{ }^{\circ} \mathrm{C}$ sodium bicarbonate decomposes according to the reaction [8]:

$2 \mathrm{NaHCO}_{3} \leftrightarrow \mathrm{Na}_{2} \mathrm{CO}_{3}+\mathrm{H}_{2} \mathrm{O}+\mathrm{CO}_{2}$

This reaction is reversible. When processing in an 
autoclave, all the components of the decomposition and formation of sodium bicarbonate are in the volume of the solution in an active freshly formed form. The components of the mineral raw materials during processing react with the solution, form water-soluble hydrocarbonate salts, and exit the mineral structure. Further, due to the high temperature, they decompose with the formation of less soluble carbonates, which serve as the basis for the formation of a new mineral structure. The phase composition of chromite ore after the activation with sodium bicarbonate is shown in the table 2. As a result of the formation of carbonates, part of the sodium hydrogen carbonate is irreversibly converted to sodium carbonate, which leads to an increase in pulp $\mathrm{pH}$ and inhibition of the hydrocarbon salts formation.
The introduction of a solution of sodium bicarbonate and chromite-containing ore into a pulp of a gas containing $12-14 \% \mathrm{CO}_{2}$, in a predetermined ratio of gas volume to pulp volume, shifts the equilibrium of reaction (1) to the left and eliminates the inhibition of the hydrocarbon salts formation, which increases the efficiency of processing.

The new mineral structure allows one to obtain a richer chromite-containing concentrate during gravitational enrichment, which can be explained by the disclosure of the surface of individual phases.

The analysis of the resulting sludge activation showed (Figure 1) that the chemical composition of the samples varies slightly, but, as follows from X-ray phase analysis, their phase composition changes (Figure 2).

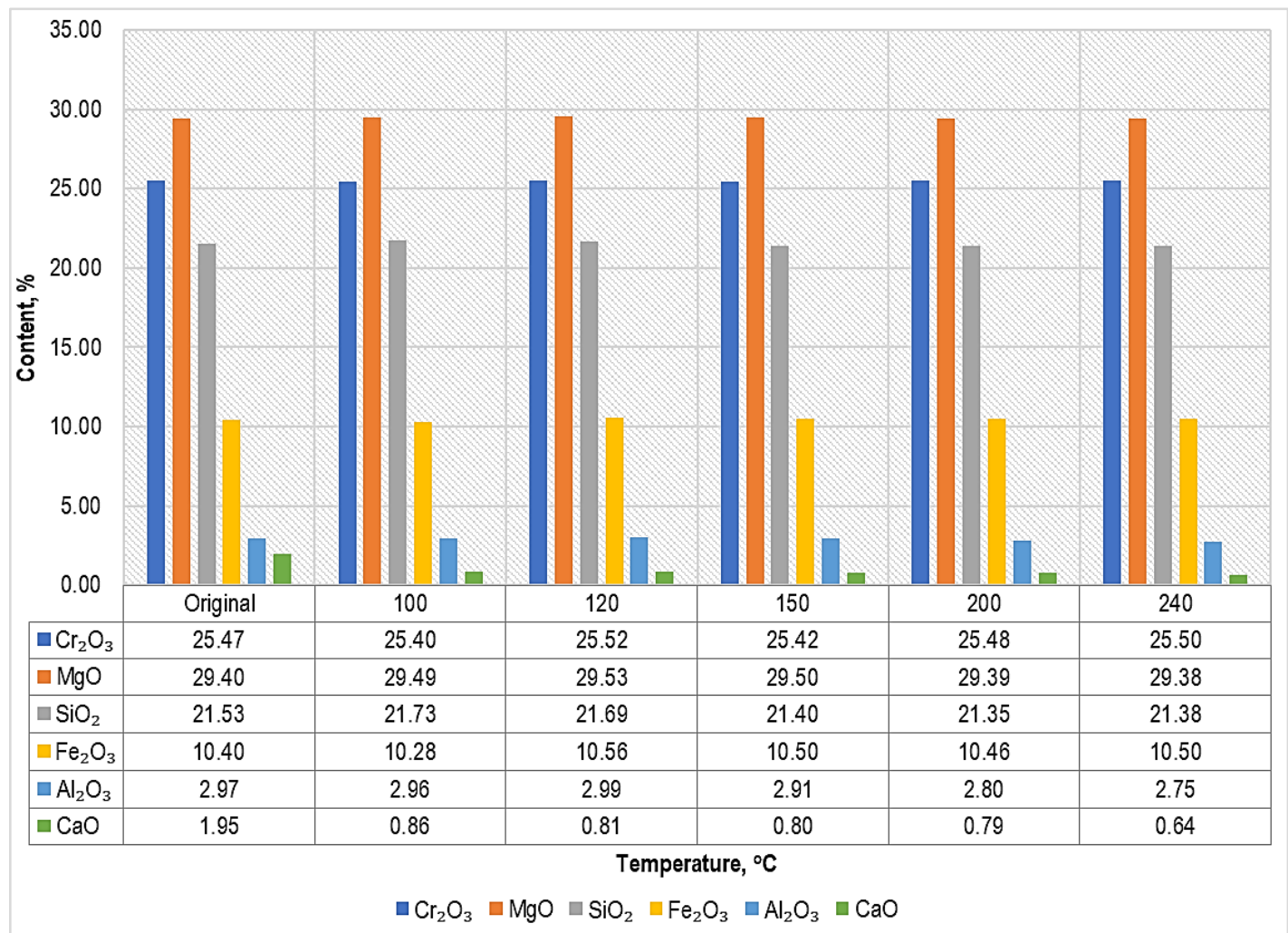

Figure 1 The chemical composition of the sludge after activation at a temperature of from 100 to $240{ }^{\circ} \mathrm{C}$

The analysis of the dependence of the phase composition of the sludge on the activation temperature shows that at a temperature of $120{ }^{\circ} \mathrm{C}$, almost all the main changes are over.

The physicochemical analysis of the phase composition of the sludge was carried out before and after the activation at a temperature of $120{ }^{\circ} \mathrm{C}$ by thermal analysis and infrared spectroscopy (IR).

The thermal analysis of the samples was carried out using an STA 449 F3 Jupiter synchronous thermal analysis instrument. Before heating, the furnace space was pumped out (achieved vacuum level $\sim 92 \%$ ) and 
then purged with an inert gas for 5 minutes. The heating was carried out at a speed of $100{ }^{\circ} \mathrm{C} / \mathrm{min}$. in an atmosphere of highly purified argon. The total volume of incoming gas was kept within $80 \mathrm{ml} / \mathrm{min}$. The results obtained using the STA 449 F3 Jupiter were processed using NETZSCH Proteus software.

The thermogram of the sludge after the activation is shown in Figure 3.

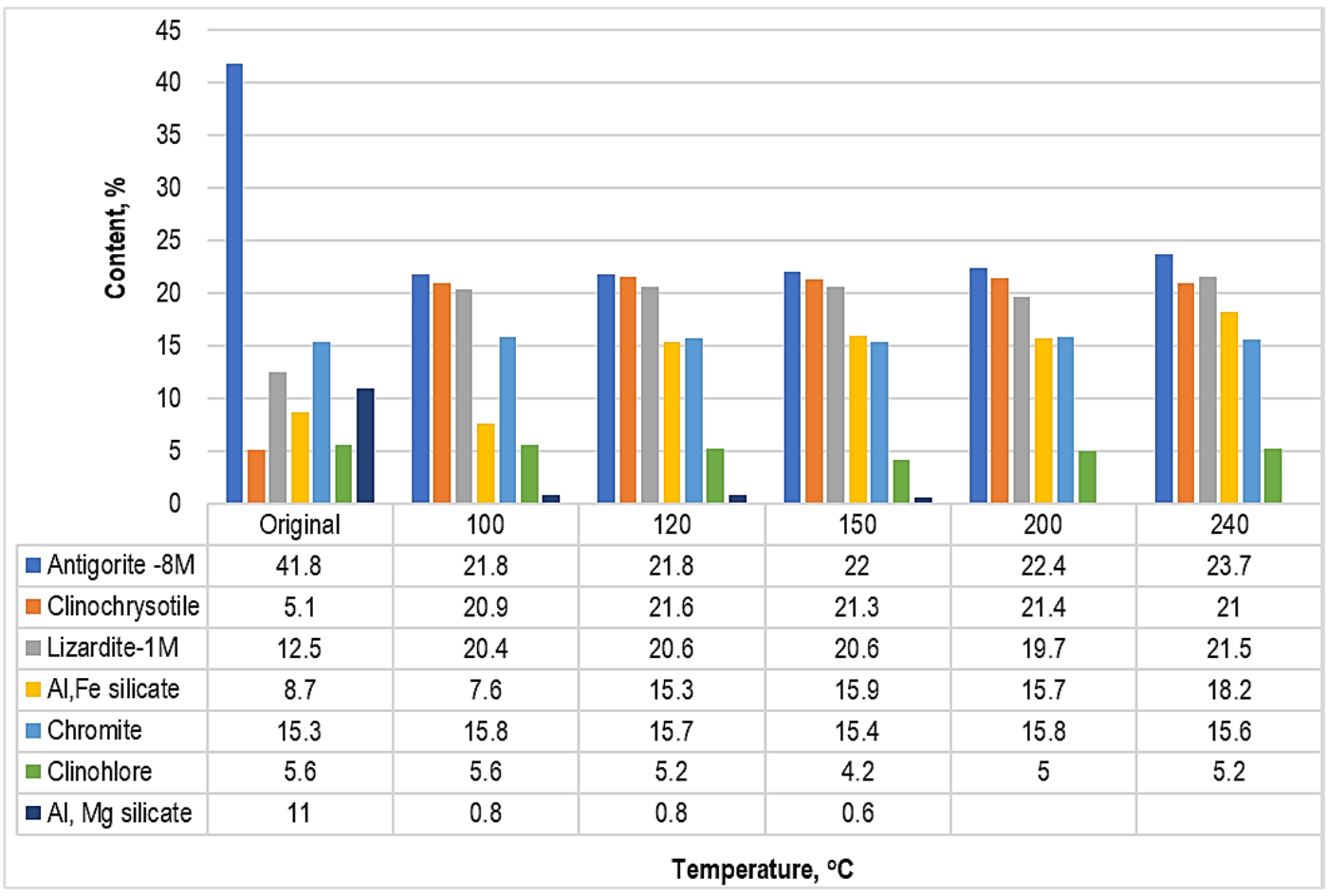

Figure 2 The phase composition of the sludge after activation at a temperature of from 100 to $240^{\circ} \mathrm{C}$

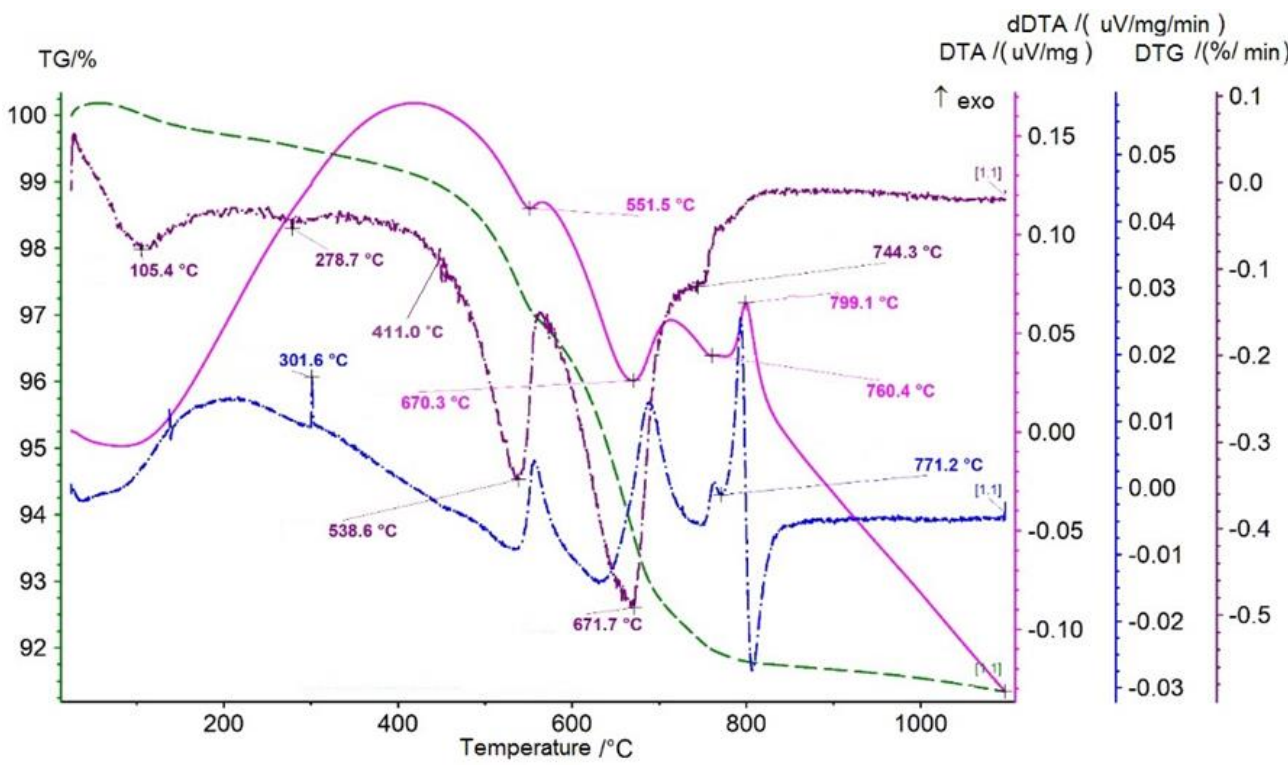

Figure 3 Thermogram of sludge after activation 
An endothermic effect with an extremum at $551.5^{\circ} \mathrm{C}$, an intense endothermic effect with maximum development at $670.3{ }^{\circ} \mathrm{C}$, and a weak endothermic effect with an extremum at $760.4{ }^{\circ} \mathrm{C}$ appeared on the DTA curve. There was also an exothermic effect with a peak at $799.1^{\circ} \mathrm{C}$. An additional endothermic effect with an extremum at $771.2{ }^{\circ} \mathrm{C}$ and a weak exothermic peak at $301.6{ }^{\circ} \mathrm{C}$ were recorded on the dDTA curve. Endothermic effects are developed against the background of a decreasing mass of the sample.

Compared to the sample of the initial sludge, chromite and iron hydroxides did not appear in the sample under consideration, with the exception of an admixture of amorphous hydroxide, the presence of which reflects a minimum on the DTG curve at $105.4{ }^{\circ} \mathrm{C}$ and a weak exothermic peak at $301.6^{\circ} \mathrm{C}$ on the dDTA curve. Also, in the temperature range of $600-700{ }^{\circ} \mathrm{C}$ there is only one endothermic effect on the dDTA curve. In the sample in this area, 4 endothermic effects were recorded. The temperatures of the extrema of the endothermic effects shifted toward higher values. In addition, a new endothermic effect appeared - with an extremum at $551.5{ }^{\circ} \mathrm{C}$. The intensity of the crystallization peak was reduced $\left(799.1^{\circ} \mathrm{C}\right)$, which is associated with a decrease in the portion of chlorites.
Epidote and margarite did not appear.

Presumably, the activation led to the formation of iron carbonate. Its manifestation may reflect an endothermic effect with the maximum development at $551.5^{\circ} \mathrm{C}$. Iron hydroxides reacted. Therefore, they are practically absent in the studied thermogram. It is worth noting that, in an overlay, this effect is combined with an exo effect at $799.1{ }^{\circ} \mathrm{C}$. the manifestation of ferrous chlorite afrosiderite.

At temperatures above $500^{\circ} \mathrm{C}$, another endothermic effect with the maximum development at $538.6{ }^{\circ} \mathrm{C}$ appeared on the DTA curve, and a weak endothermic effect with an extremum at $278.7^{\circ} \mathrm{C}$ appeared on the dDTA curve.

It can be assumed that, as a result of the activation, the peak of the decomposition and dehydration of $\mathrm{Mg}_{6} \mathrm{Cr}_{2}\left[\mathrm{CO}_{3}\right](\mathrm{OH})_{16} 4 \mathrm{H}_{2} \mathrm{O}$ shifted to $538.6^{\circ} \mathrm{C}$ compared to $411{ }^{\circ} \mathrm{C}$ in the initial sample.

Thus, according to thermal analysis data, after the activation, the sludge contains serpentine, possibly one chlorite, an admixture of amorphous iron hydroxide, iron carbonate, complex magnesium-chromium carbonate, and magnesium carbonate.

After the pre-activation, at $120^{\circ} \mathrm{C}$, the sludge was sent to gravity concentration (Figure 4).

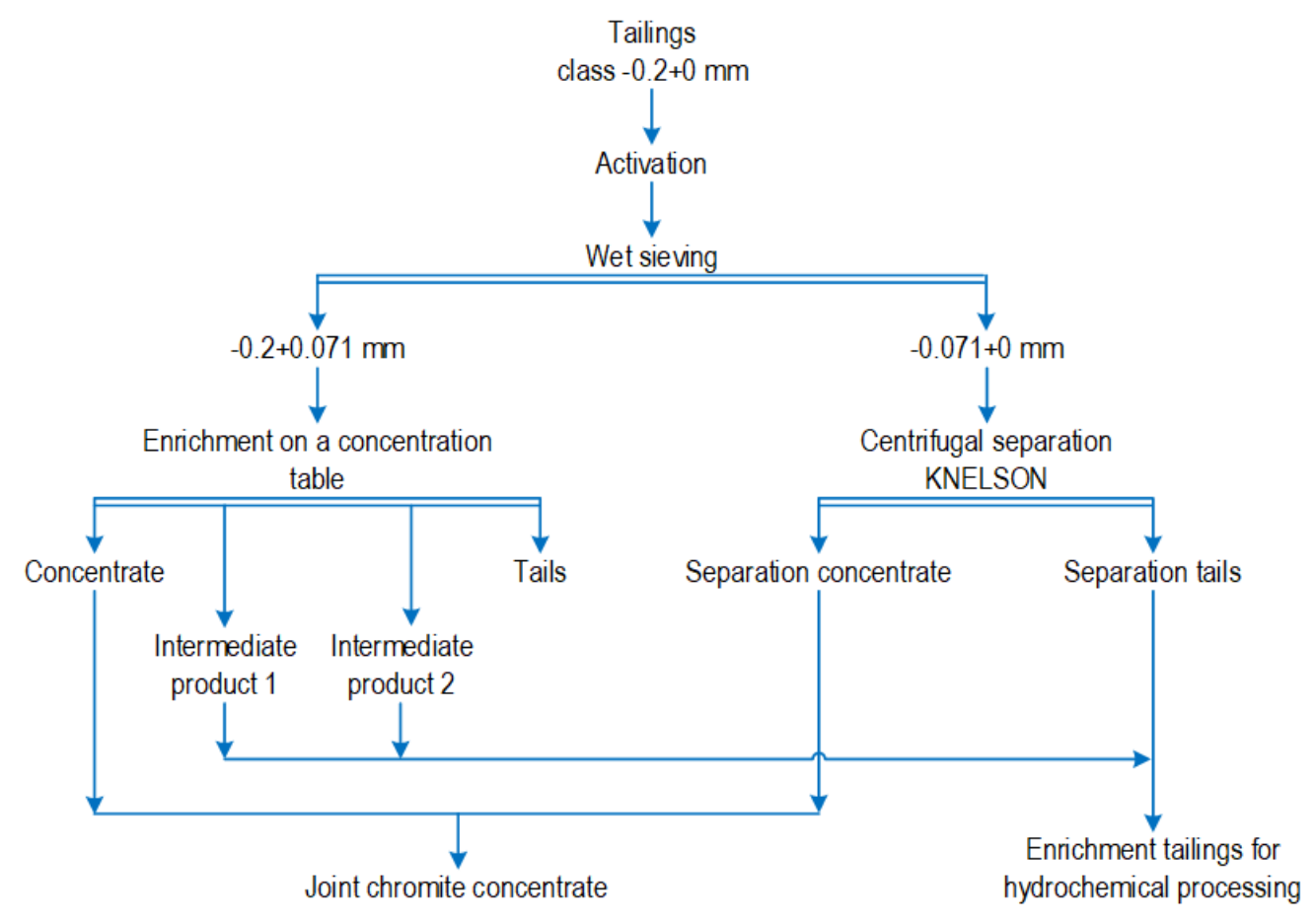

Figure 4 Scheme of gravity concentration 
Technology for processing tailings chrome ore includes the benefication of the fine fraction $-0.2+0 \mathrm{~mm}$ of the beneficiation plant tailings using gravity methods [9]. The studies were carried out on the gravitational beneficiation of chromite sludge of fineness class $-0.2+0.071 \mathrm{~mm}$ on the concentration table CKO-1 (Figure 5) and fineness class $-0.071+0 \mathrm{~mm}$ on the FLSmidth Knelson centrifugal concentrator model KS-MD3 (Figure 6).

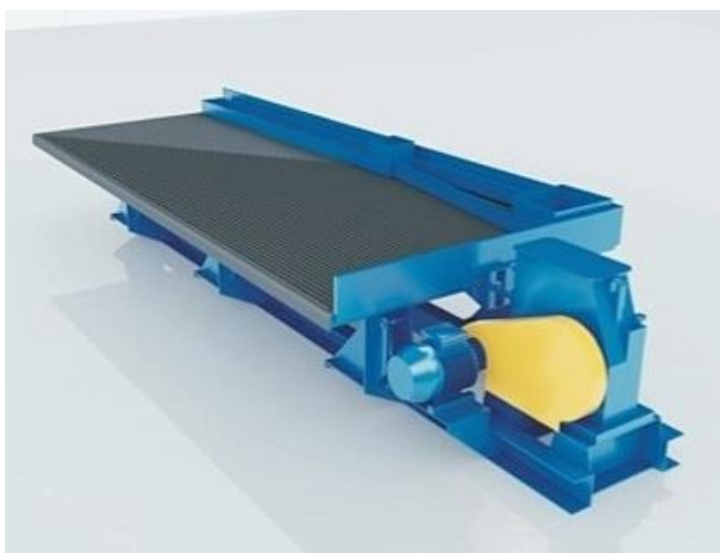

Figure 5 Concentration table CKO-1

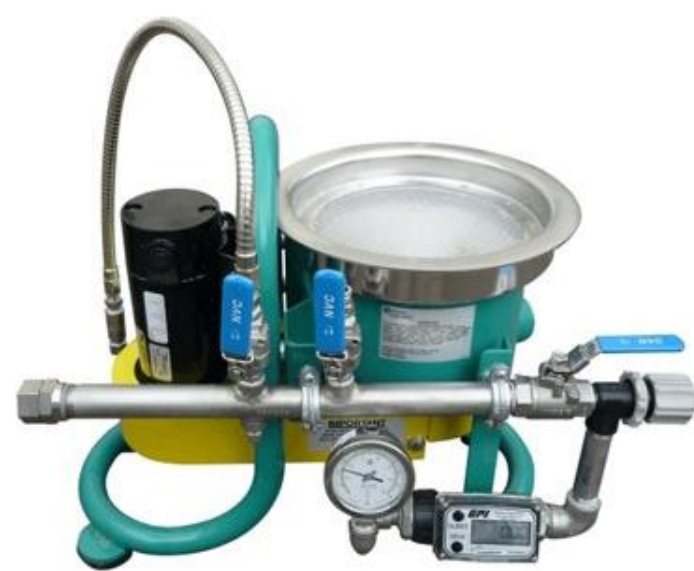

Figure 6 Knelson centrifugal concentrator

As a result of the concentration of sludge class $-0.2+0.071 \mathrm{~mm}$, the concentrate with the $\mathrm{Cr}_{2} \mathrm{O}_{3}$ content of $52.33 \%$ was obtained at the concentration table (table $3)$.

The results of the concentration of the sludge class $-0.071+0 \mathrm{~mm}$ on the KNELSON centrifugal separator are shown in Table 4.
Thus, when combining gravity concentration concentrates obtained from the classes $-0.2+0.071 \mathrm{~mm}$ and $-0.071+0 \mathrm{~mm}$ on the concentration table and the centrifugal separator, the combined concentrate with a $\mathrm{Cr}_{2} \mathrm{O}_{3}$ content of $51.3 \%$ with a yield of $41.7 \%$ was obtained. The extraction of $\mathrm{Cr}_{2} \mathrm{O}_{3}$ in the combined concentrate was $68.1 \%$.

Table 3 The results of the concentration of sludge after activation on the concentration table

\begin{tabular}{|c|c|c|c|}
\hline Name & Output, \% & $\begin{array}{c}\mathrm{Content} \mathrm{of} \\
\mathrm{Cr}_{2} \mathrm{O}_{3}, \%\end{array}$ & $\begin{array}{c}\text { Extraction of } \\
\mathrm{Cr}_{2} \mathrm{O}_{3}, \%\end{array}$ \\
\hline Concentrate & 26.42 & 52.33 & 68.51 \\
\hline $\begin{array}{c}\text { Intermediate } \\
\text { product 1 }\end{array}$ & 58.11 & 9.07 & 26.14 \\
\hline $\begin{array}{c}\text { Intermediate } \\
\text { product 2 }\end{array}$ & 8.36 & 5.83 & 2.42 \\
\hline Tails & 7.11 & 8.33 & 2.93 \\
\hline Total: & 100.0 & 20.17 & 100.0 \\
\hline
\end{tabular}

Table 4 The results of the concentration of sludge after activation on a centrifugal separator KNELSON

\begin{tabular}{|c|c|c|c|}
\hline Name & Output, \% & $\begin{array}{c}\mathrm{Content} \text { of } \\
\mathrm{Cr}_{2} \mathrm{O}_{3}, \%\end{array}$ & $\begin{array}{c}\text { Extraction of } \\
\mathrm{Cr}_{2} \mathrm{O}_{3}, \%\end{array}$ \\
\hline $\begin{array}{c}\text { Separation } \\
\text { concentrate }\end{array}$ & 41.3 & 51.22 & 63.15 \\
\hline Separation tails & 58.7 & 21.03 & 36.85 \\
\hline Total: & 100.0 & 33.49 & 100.0 \\
\hline
\end{tabular}

To compare the results, the experiments were carried out on gravity enrichment without the activation (Tables 5, 6).

Table 5 The results of the concentration of sludge without activation on the concentration table

\begin{tabular}{|c|c|c|c|}
\hline Name & Output, \% & $\begin{array}{c}\mathrm{Content} \text { of } \\
\mathrm{Cr}_{2} \mathrm{O}_{3}, \%\end{array}$ & $\begin{array}{c}\text { Extraction of } \\
\mathrm{Cr}_{2} \mathrm{O}_{3}, \%\end{array}$ \\
\hline Concentrate & 29.42 & 48.8 & 73.02 \\
\hline $\begin{array}{c}\text { Intermediate } \\
\text { product }\end{array}$ & 14.3 & 11.5 & 8.36 \\
\hline Tails & 56.28 & 6.5 & 18.62 \\
\hline Total: & 100.0 & 15.64 & 100.0 \\
\hline
\end{tabular}

Thus, the operation of pre-activation of the tailings made it possible to obtain a concentrate $8.42 \%$ richer than with the enrichment without the activation. 
Table 6 The results of the concentration of sludge without activation on a centrifugal separator KNELSON

\begin{tabular}{|c|c|c|c|}
\hline Name & Output, \% & $\begin{array}{c}\text { Content of } \\
\mathrm{Cr}_{2} \mathrm{O}_{3}, \%\end{array}$ & $\begin{array}{c}\text { Extraction of } \\
\mathrm{Cr}_{2} \mathrm{O}_{3}, \%\end{array}$ \\
\hline $\begin{array}{c}\text { Main separation } \\
\text { concentrate }\end{array}$ & 48.5 & 42.8 & 66.64 \\
\hline $\begin{array}{c}\text { Control } \\
\text { separation } \\
\text { concentrate }\end{array}$ & 13.6 & 32.8 & 14.2 \\
\hline Separation tails & 37.9 & 15.75 & 19.16 \\
\hline Total: & 100.0 & 31.14 & 100.0 \\
\hline
\end{tabular}

\section{Conclusions}

According to the studies, the new mineral structure allows obtaining a richer chromite-containing concentrate during the gravitational enrichment, which can be explained by the disclosure of the surface of the individual phases.

The analysis of the obtained activation of sludge showed that the chemical composition of the samples varies slightly, but, as follows from $x$-ray phase analysis, their phase composition changes.

According to thermal analysis, after the activation, the sludge contains serpentine, possibly one chlorite, an admixture of amorphous iron hydroxide, iron carbonate, complex magnesium-chromium carbonate, and magnesium carbonate.

When combining the concentrations of the gravity concentrate on the concentration table and the centrifugal separator obtained from the classes $-0.2+0.071 \mathrm{~mm}$ and $-0.071+0 \mathrm{~mm}$, a combined concentrate was obtained with the $\mathrm{Cr}_{2} \mathrm{O}_{3}$ content of $51.3 \%$ with a yield of $41.7 \%$. The extraction of $\mathrm{Cr}_{2} \mathrm{O}_{3}$ to the combined concentrate was $68.1 \%$.

During gravitational concentration, a total chromite concentrate containing $51.3 \% \mathrm{Cr}_{2} \mathrm{O}_{3}$ was obtained. The yield of concentrate was $41.7 \%$. The extraction of $\mathrm{Cr}_{2} \mathrm{O}_{3}$ to the concentrate was $68.1 \%$.

Gravity equipment (concentric table, centrifugal separator) included in the technological scheme is successfully used on an industrial scale [10].

\section{Note}

A part of this study was presented at the XIII International Mineral Processing and Recycling Conference, organized by the University of Belgrade,
Technical Faculty in Bor, from 8th to 10th May 2019, Belgrade, Serbia.

\section{References}

[1] Ryabin V.A., Popilsky M.Ya., Soloshenko A.A. Modern technologies for processing chrome ores, neutralization and disposal of toxic waste, International Scientific and Technical Conference on the Processing of Technogenic Formations, Ekaterinburg, Russia, 1997, p. 59-61.

[2] Garkunova N.V., Plyshevsky Yu.S. Use of industrial wastes containing olevin-serpentine rocks for the production of magnesium compounds, XIII International Conference Exhibition "Uralecology. Technogen 2003", Ekaterinburg, Russia, 2003, p. 320.

[3] Leontiev, L.I., Sheshukov, O.Yu., Nekrasov, I.V. Analysis of the processing and use of industrial wastes of metallurgical production, Complex use of mineral raw materials, (4) 2014, p. 8-25.

[4] Savelyev D.E., Ilaltdinov I.Ya., Bazhin E.A. To the Problem of Practical Use of Immediated Chromium Ores of the Saksey-Kluchevskaya Area of Massiv of Middle Krak (South Ural), Bulletin of Perm University, 1(30) 2016, p. 88-97.

[5] Semidalov S.Yu., Nevsky Yu.N., Bushueva N.Yu., Sergeev G.I., Melnichenko A.F., Rogov V.M. Patent 2136376, publ. 10.09.99 (4), Russia.

[6] Abdulvaliyev R.A., Abdykirova G.Zh., Dyussenova S.B., Imangalieva L.M. Beneficiation of chromitecontaining sludge, Obogashchenie Rud, (6) 2017, p. 27-31.

[7] Gladyshev, S.V., Abdulvaliev, R.A., Kenzhaliev, B.K., Dyusenova, S.B., Imangaliyeva, L.M. Obtaining chrome concentrate from tailings, Complex use of mineral raw materials, (1) 2018, $p$. 12-17.

[8] Kunyants I.L. Chemical Encycloped, Moskow, Russia, 1992. p. 139.

[9] S. Dyussenova, B. Kenzhaliyev, R. Abdulvaliev, S. Gladyshev. Processing of chromite plant tailing, XIII International Mineral Processing and Recycling Conference, Belgrade, Serbia, 2019, p. 178-182.

[10] T. Greyver. Study of chromite platinum metal arrays in Russia, New technologies in metallurgy, chemistry, enrichment and ecology, St. Petersburg: Notes of the Mining Institute, 2006, p. 173-177. 


\title{
METODA PRERADE TEHNOGENE SIROVINE HROMA
}

\section{S. Dyussenova ${ }^{1 \#}$, B. Kenzhaliyev'1, R. Abdulvaliyev¹, S. Gladyshev ${ }^{1}$}

1Satbayev University, Institute of Metallurgy and Ore Beneficiation JSC, Almaty, Kazakhstan

(Primljen: 1. oktobar 2019.; Prihvaćen: 22. januar 2020.)

\begin{abstract}
Izvod
Uzimajući u obzir postojeću potražnju za koncentratima hroma, ekstrakcija hroma iz tehnogenih ležišta mulja nastalih preradom hroma je važan praktičan zadatak. Sveobuhvatno iskorišćenje koncentracije mulja će povećati profitabilnost proizvodnje i rešiti probleme očuvanja životne sredine u regionu.

Važnost rešenja problema uključivanja u preradu jalovine je povezana ne samo sa zaštitom okoline, već $i$ sa potrebom da se poveća proizvodnja hroma. Moderne tehnologije gravitacijske koncentracije omogućavaju da se efikasno proizvede koncentrat hroma iz velikih $i$ srednjih delova rude sa sadržajem hromita, dok kod fino usitnjenog mulja to praktično nije moguće jer je teško izdvojiti kompleksne minerale $u$ koncentrate $i$ jalovinu. $U$ ovom radu su predstavljeni rezultati istraživanja u vezi sa gravitacijskom preradom jalovine.

Ova tehnologija uključuje koncentraciju finih klasa -0,2+0 $\mathrm{mm}$ jalovine, nastale preradom rude sa sadržajem hromita, gravitacionom metodom uz korišćenje KNELSON centrifugalnog separatora. Efikasnost gravitacijske koncentracije se u tehnologiji obezbeđuje preliminarnom aktivacijom finih klasa u rastvoru natrijum bikarbonata $\left(\mathrm{NaHCO}_{3}\right)$.

Gravitacijskom koncentracijom postignut je ukupan koncentrat hromita sa $51,3 \% \quad \mathrm{Cr}_{2} \mathrm{O}_{3}$. Proizvodnja koncentrata bila je $41,7 \%$. Ekstrakcija $\mathrm{Cr}_{2} \mathrm{O}_{3}$ iz koncentrata bila je $68,1 \%$.
\end{abstract}

Ključne reči: Ruda sa sadržajem hromita; Gravitaciono obogaćivanje; Jalovina; Koncentrat. 